\title{
MEDIASI SAFETY KNOWLEDGE DAN SAFETY MOTIVATION PADA PENGARUH SAFETY MANAGEMENT PRACTICES TERHADAP SAFETY PERFORMANCE KARYAWAN BAGIAN PRODUKSI PT.PETROKIMIA GRESIK
}

\author{
Novi Aditya Rosalita, Dwi Ratmawati, dan Tri Siwi Agustina \\ Magister Sains Manajemen Universitas Airlangga
}

\begin{abstract}
Safety management practices not only improve working conditions but also positively influence employees' attitudes and behaviours with regard to safety, thereby reducing accidents in workplace. This study measured employees' perceptions on six safety management practices and self-reported safety knowledge, safety motivation, safety compliance and safety participation.The study conducting a survey using questionnaire among 69 pelaksana Produksi Pabrik III PT. Petrokimia Gresik. The reliability and validity of all the indicators were found acceptable. Data are analyzed using Partial Least Square (PLS) with SmartPLS version 2.0.The result is safety management practices have direct and significant influence to safety performance, safety management practices have indirect and significant influence to safety performance through safety knowledge, and safety management practices have indirect influence to safety performance through safety motivation.
\end{abstract}

Keywords: Safety management practices, safety knowledge, safety motivation, safety compliance, safety participation.

\section{PENDAHULUAN}

PT. Petrokimia Gresik merupakan perusahaan BUMN (Badan Usaha Milik Negara) dalam lingkup Departemen Perindustrian dan Perdagangan yang bergerak dalam bidang produksi pupuk, bahan-bahan kimia (H2SO4, H2PO4, CO2, cement retarder, aluminium fluoride) dan jasa lainnya seperti konstruksi dan engineering (pembuatan Boiler). PT. Petrokimia Gresik merupakan pabrik pupuk tertua kedua di Indonesia setelah PT. Pupuk Sriwijaya (PUSRI) di Palembang dan juga merupakan pabrik pupuk terlengkap di antara pabrik pupuk lainnya.Dalam proses produksinya pelaksana produksi PT. Petrokimia Gresik sangat dekat dengan pekerjaan, yang bertugas secara langsung untuk mengelola bahan mentah menjadi produk jadi, karyawan ini beresiko mengalami kecelakaan kerja karena menggunakan peralatan mesin yang kompleks, maka dari itu perlu untuk mematuhi segala peraturan dan prosedur keselamatan agar dapat meminimalisir terjadinya kecelakaan kerja. Pelaksana produksi yang paling rentan terhadap bahaya ialah pelaksana produksi pada pabrik III, karena lingkungannya paling bising, menggunakan peralatan berat, paling berdebu, paling banyak limbah, dan lingkungan kerja panas. Maka dari itu keselamatan dan Kesehatan Kerja (K3) menjadi aspek yang sangat penting dalam proses produksi yang dilakukan di PT. Petrokimia Gresik, yang berguna untuk menciptakan lingkungan kerja yang aman, sehat dan berbudaya K3. K3 merupakan modal PT. Petrokimia Gresik dalam mencapai tujuan perusahaan yaitu menjadi produsen pupuk dan produk kimia lainnya yang berdaya saing tinggi dan produknya paling diminati konsumen dengan kinerja unggul dan 


\section{Novi Aditya Rosalita \\ Dwi Ratmawati \\ Tri Siwi Agustina}

berkelanjutan.Dalam menjalankan tujuan tersebut PT. Petrokimia Gresik didukung oleh "Sistem Manajemen Keselamatan dan Kesehatan Kerja" yang telah di aplikasikan oleh perusahaan.

Namun seiring perubahan lingkungan, sistem manajemen keselamatan dan kesehatan pada PT. Petrokimia Gresik belum cukup optimal dalam menekan frekuensi kecelakaan kerja yang terjadi, hal ini dibuktikan dengan adanya beberapa kasus kecelakaan kerja pada pelaksana produksi pabrik III, seperti yang dijelaskan oleh bagian keselamatan dan kesehatan kerja PT. Petrokimia Gresik yang telah diwawancarai dalam penelitian ini bernama Bapak Arifin merupakan staff bagian K3, yang dirangkum dalam tabel 1.1 dibawah ini:

Tabel 1.1 Kecelakaan Kerja Pelaksana Produksi Pabrik III

\begin{tabular}{|l|l|l|l|}
\hline No. & Tahun & Kronologi & Hasil Investigasi K3 \\
\hline 1 & 2013 & $\begin{array}{l}\text { Pelaksana Produksi Pabrik III } \\
\text { meninggal dunia akibat ledakan } \\
\text { reaktor kimia }\end{array}$ & $\begin{array}{l}\text { Tidakan tidak sesuai dengan } \\
\text { prosedur keselamatan } \\
\text { (mengabaikan safety permit) }\end{array}$ \\
\hline 2 & 2014 & $\begin{array}{l}\text { Pelaksana Produksi Pabrik III } \\
\text { mengalami kecelakaan kerja } \\
\text { hingga meninggal dunia karena } \\
\text { terjatuh dari ketinggian 7-10 }\end{array}$ & $\begin{array}{l}\text { Tidak memakai perlindungan } \\
\text { diri (helm keselamatan) dan } \\
\text { tidak hati-hati dalam } \\
\text { memasang tali pengaman }\end{array}$ \\
\hline 3 & 2015 & $\begin{array}{l}\text { Pelaksana Produksi Pabrik III } \\
\text { mengalami kecelakaan kerja } \\
\text { hingga meninggal dunia karena } \\
\text { terjatuh dari ketinggian 7 meter } \\
\text { saat mengecek sumbatan } \\
\text { penguras limbah }\end{array}$ & $\begin{array}{l}\text { Tidak memakai perlindungan } \\
\text { diri (helm keselamatan) dan } \\
\text { tidak hati-hati dalam } \\
\text { memasang tali pengaman }\end{array}$ \\
\hline
\end{tabular}

Sumber: Hasil wawancara staff bagian K3

Berdasarkan informasi-informasi tersebut, terlihat bahwa kecelakaan kerja pada PT. Petrokimia Gresik masih sering terjadi dari tahun ke tahun.Kecelakaan kerja yang sering terjadi menunjukan bahwa safety performance dari karyawan kurang optimal, hal ini diperkirakan karena karyawan cenderung berperilaku untuk mengabaikan keselamatan.Perilaku yang cenderung mengabaikan keselamatan ini mencerminkan terjadi penurunan safety performance karyawan.Safety performance menurut Griffin dan Neal (2000) terbentuk dari safety compliance dan safety participation.Safety compliance merupakan perilaku keselamatan yang dilakukan oleh individu dalam menjaga keselamatan, sedangkan safety participation merupakan perilaku individu untuk berpartisipasi dalam aktivitas keselamatan.Kasus kecelakaan kerja diatas seperti terjadi ledakan reaktor menunjukan bahwa karyawan bekerja tidak sesuai dengan prosedur keselamatan yang berlaku di dalam perusahaan. Sedangkan kasus karyawan yag terjatuh dari ketinggian 7-10 meter menunjukan bahwa karyawan tidak patuh menggunakan peralatan perlindungan diri yang lengkap. Kasus-kasus tersebut dapat diartikan bahwa karyawan pelaksana produksi pabrik III cenderung berperilaku mengabaikan keselamatan.Maka dari itu penelitian ini sesuai menggunakan referensi safety performance dari Griffin dan Neal (2000) karena dalam penelitian ini ingin mengukur perilaku pelaksana produksi pabrik III untuk memprioritaskan keselamatannya. 


\section{Jurnal Manajemen Teori dan Terapan Tahun 8. No. 3, Desember 2015}

Kasus kecelakaan yang terjadi pada pelaksana produksi pabrik III PT. Petrokimia Gresik menunjukkan kecenderungan safety performance yang rendah dari karyawan, maka dari itu safety performance karyawanperlu untuk ditingkatkan dengan cara meningkatkan safety knowledge karyawan. Menurut Vinodkumar dan Bhasi (2010) bahwa safety knowledge merupakan pengetahuan karyawan terhadap praktek dan prosedur keselamatan. Dalam PT. Petrokimia Gresik cara untuk meningkatkan pengetahuan keselamatan kepada karyawan ialah dengan mengadakan berbagai macam pelatihan seperti pelatihan menggunakan peralatan perlindungan diri yang benar, pelatihan mengetahui jenis-jenis bahaya, pelatihan cara penanggulanggan situasi darurat yang tepat apabila terjadi kecelakaan. Juga diperlukan pula meningkatkan safety motivation karyawan dengan cara terus memotivasi karyawan untuk melaksanakan peraturan dan prosedur keselamatan, memotivasi karyawan untuk konsisten menggunakan peralatan keselatan, dan memotivasi karyawan untuk membatu rekan kerja yang berada dalam masalah keselamatan. Hal ini dapat ditingkatkan apabila PT. Petrokimia Gresik mengoptimalkan peran dari safety management practices. Vinodkumar dan Bhasi (2010) menyatakan bahwa safety management practices merupakan praktek, peran dan fungsi manajemen yang dirancang oleh perusahaan untuk meningkatkan keselamatan karyawan tentang komitmen manajemen terkait keselamatan, pelatihan keselamatan, pelibatan pekerja dalam memecahkan masalah keselamatan, komunikasi keselamatan, peraturan dan prosedur keselamatan, dan penghargaan keselamatan yang sesuai dengan bahaya kerja. Maka dari itu penelitian ini sesuai menggunakan referensi safety management practices, safety knowledge dan safety motivation dari Vinodkumar dan Bhasi (2010) karena pada penelitian ini berupaya untuk mengukur safety performance karyawan, yang dapat ditingkatkan dengan meningkatkan safety knowledge dan safety motivation, hal ini dapat dicapai dengan cara mengoptimalkan peran dari safety management practices, dimana indikator yang digunakan di dalam teori Vinodkumar dan Bhasi (2010) sesuai dengan yang diaplikasikan oleh manajemen PT. Petrokimia Gresik.

Berdasarkan fenomena diatas, maka penelitian ini tertarik untuk melakukan penelitian dengan berupaya meningkatkan safety performance dari pelaksana produksi pabrik III, dengan cara meningkatkan safety knowledge dan safety motivation dengan mengoptimalkan peran dari safety management practices. Sehingga penelitian ini memiliki judul "Pengaruh Safety Management practices terhadap Safety Performance dengan variabel mediasi safety knowledge dan safety motivation pada pelaksana produksi pabrik III PT Petrokimia Gresik".

\section{HIPOTESIS}

\section{Pengaruh Safety Management Practices terhadap Safety Performance}

Vinodkumar dan Bhasi (2010) menemukan bahwa safety management practices memiliki pengaruh terhadap safety performance. Selanjutnya temuan Vinodkumar dan Bhasi (2010) menyebutkan bahwa dimensi dari safety management practices (komitmen manajemen, keterlibatan karyawan, peraturan dan prosedur keselamatan, dan safety promotion polices) mempunyai pengaruh langsung terhadap safety performance. Hal ini dapat dianalogikan bahwa ketika perusahaan menerapkan praktek-praktek keselamatan yang baik, misalkan dengan mempunyai 


\section{Novi Aditya Rosalita \\ Dwi Ratmawati \\ Tri Siwi Agustina}

komitmen manajemen terkait keselamatan dengan baik, selalu melibatkan karyawan dalam pengambilan keputusan keselamatan, menegakkan peraturan dan prosedur keselamatan, dan memberikan safety promotion polices dengan adil, akan berpengaruh pada peningkatkan safety performance, dengan kata lain karyawan akan lebih patuh untuk menjaga keselamatan dan ikut berpartisipasi dalam aktivitas keselamatan. Oleh karena itu safety performance dapat dianggap sebagai hasil dari interaksi faktor-faktor safety management practices. Hal ini didukung juga oleh penelitian Purnamasari (2013) bahwa terdapat pengaruh safety climate terhadap safety performance. Berdasarkan beberapa penelitian diatas, maka dapat diperoleh hipotesis sebagai berikut:

$\mathrm{Hl}$ : Safety Management Practices berpengaruh terhadap Safety Performance.

\section{Pengaruh Safety Management Practice berpengaruh terhadap Safety Performance melalui Safety Knowledge}

Vinodkumar dan Bhasi (2010) menemukan bahwa safety management practice berpengaruh terhadap safety performance, melalui safety knowledge. Selain itu Vinodkumar dan Bhasi (2010) menemukan bahwa dimensi dari safety management practices yang paling berpengaruh dalam meningkatkan safety knowledge ialah safety training, serta ditunjang dengan adanya upaya untuk menyampaikan informasi keselamatan dengan baik, adanya ketegasan untuk menerapkan peraturan dan prosedur keselamatan, maka dapat meningkatkan safety knowledge dimana pengetahuan karyawan terhadap praktek dan prosedur keselamatan akan meningkat, yang pada akhirnya dapat dapat meningkatkan perilaku keselamatan karyawan (safety performance), terutama yang berkaitan dengan karyawan lebih patuh untuk menjaga keselamatan (safety compliance) serta turut berpartisipasi mengikuti aktivitas keselamatan (safety participation). Hasil penelitian ini juga didukung oleh penelitian Griffin dan Neal (2000) menyebutkan bahwa safety knowledge memediasi hubungan safety climate terhadap safety performance. Berdasarkan beberapa penelitian diatas, maka dapat diperoleh hipotesis sebagai berikut:

H2: Safety Management Practice berpengaruh terhadap safety performance melalui safety knowledge

\section{Pengaruh Safety Management Practices terhadap Safety Performance melalui Safety Motivation}

Vinodkumar dan Bhasi (2010) menemukan bahwa safety management practice berpengaruh terhadap safety performance melalui safety motivation. Penelitian ini juga menemukan bahwa safety training merupakan dimensi yang paling berpengaruh untuk meningkatkan safety motivation dari karyawan. Hal ini dapat diasumsikan bahwa ketika perusahaan memberikan karyawan safety training dengan baik maka dapat meningkatkan dorongan dalam diri karyawan untuk melakukan tindakan keselamatan. Jika karyawan terdorong untuk bekerja dengan keselamatan yang tinggi maka akan meningkatkan safety performance sehingga karyawan lebih patuh untuk menjaga keselamatan (safety compliance) serta turut berpartisipasi mengikuti aktivitas keselamatan (safety participation). Hasil penelitian ini didukung oleh penelitian Grifin dan Neal (2000) yang menenukan bahwa safety motivation memediasi hubungan antara safety climateterhadap safety compliance dan safety participation yang merupakan dimensi dari variabel safety performance. 
Berdasarkan beberapa penelitian diatas, maka dapat diperoleh hipotesis sebagai berikut:

H3: Safety management practice berpengaruh terhadap safety performance melalui safety motivation.

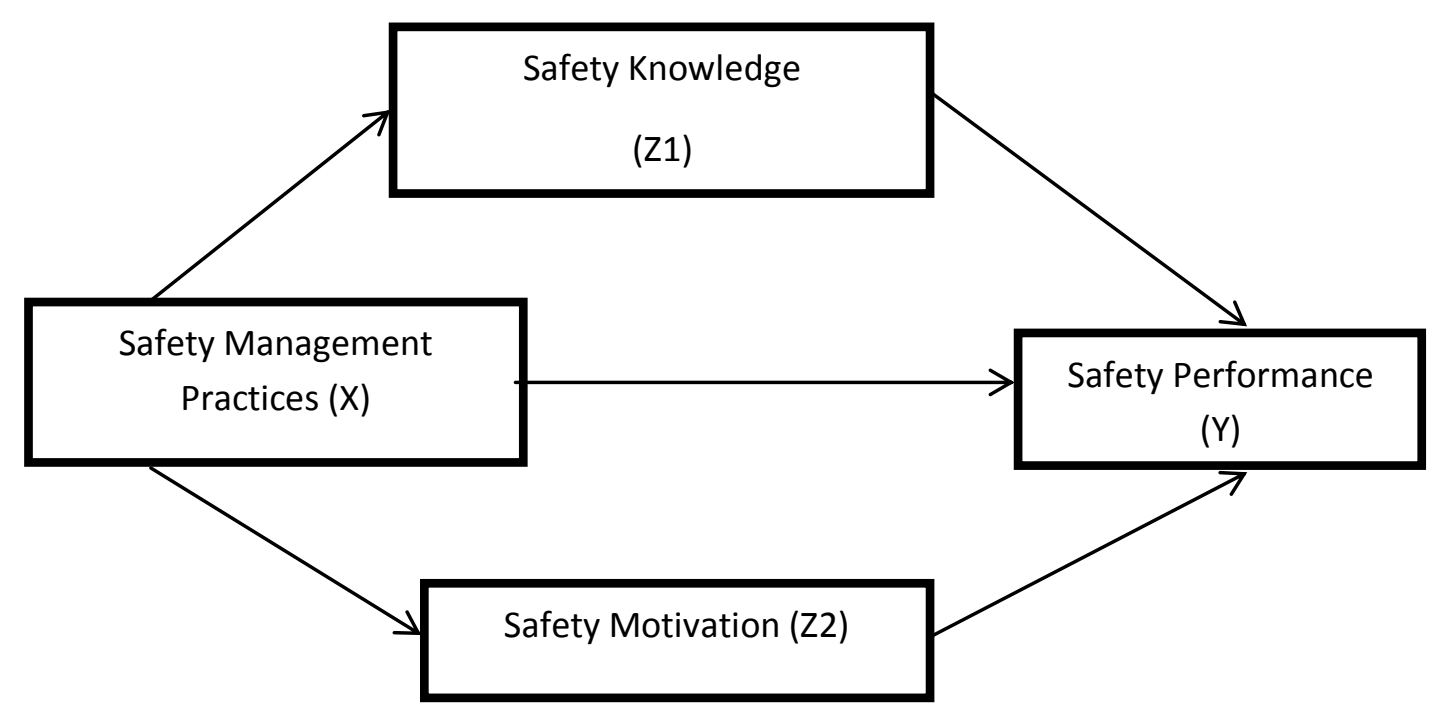

Gambar 3.1 Kerangka Konseptual

\section{METODE PENELITIAN}

Populasi dalam penelitian ini adalah keseluruhan pelaksana produksi pabrik III dengan status karyawan tetap berjumlah 221 orang.Untuk mengetahui ukuran sampel, digunakan rumus Slovin dan menghasilkan sampel akhir sebesar 69 Responden.Dalam penelitian ini teknik pengambilan sampel secara Accidental Sampling.

\section{Safety Management Practice}

Safety Management Practice merupakan praktek, peran dan fungsi manajemen yang dirancang oleh perusahaan untuk meningkatkan keselamatan karyawan (Vinodkumar dan Bhasi, 2010).Safety Management Practice mempunyai 6 dimensi :

1. Management Commitment

Magement commitment merupakan sikap atau tindakan yang dilakukan manajemen untuk memprioritaskan keselamatan karyawan (Vinodkumar dan Bhasi, 2010).Dalam penelitian ini management commitment merupakan persepsi karyawan atas tindakan yang dilakukan manajemen untuk memprioritaskan keselamatan yang 


\section{Novi Aditya Rosalita Dwi Ratmawati Tri Siwi Agustina}

diaplikasikan di PT Petrokimia Gresik.Manajemen Commitment diukur dengan 3 indikator dari Vinodkumar dan Bhasi (2010), yaitu:

a. Tindakankorektifkeselamatan.

b. Tindakan investigasikecelakaan.

c. Tindakan pengawasan pemakaian peralatan keselamatan.

\section{Safety Training}

Safety training merupakan program pelatihan yang dirancang untuk keselamatan karyawan (Vinodkumar dan Bhasi, 2010).Dalam penelitian ini safety training merupakan persepsi karyawan atas efektivitas program pelatihan yang dirancang untuk keselamatan yang diaplikasikan di PT Petrokimia Gresik. Safety Training diukur dengan 3 indikator dari Vinodkumar dan Bhasi (2010), yaitu:

a. Pelatihan keselamatan yang komprehensif.

b. Pelatihan untuk mengatasi situasi darurat.

c. Mentor yang kompeten.

3. Workers' Involvement in Safety

Workers' Involvement in Safety merupakan keterlibatan individu atau kelompok dalam memecahkan masalah keselamatan (Vinodkumar dan Bhasi, 2010).Dalam penelitian ini Workers' Involvement in Safety merupakan persepsi karyawan atas keterlibatannya untuk memecahkan permasalahan keselamatan yang diaplikasikan di PT Petrokimia Gresik.Worker' Involvement in Safety diukur dengan 3 indikator dari Vinodkumar dan Bhasi (2010), yaitu:

a. Keterlibatan dalam identifikasi masalah keselamatan.

b. Keterlibatan untuk memberi masukan terkait proses pengambilan keputusan keselamatan.

c. Keterlibatan perwakilan karyawan dalam komite keselamatan.

4. Safety Communication

Safety Communication merupakan upaya untuk menyampaikan informasi keselamatan kepada karyawan (Vinodkumar dan Bhasi, 2010).Dalam penelitian ini Safety Communication merupakan persepsi karyawan terhadap upaya penyampaian informasi keselamatan yang diaplikasikan di PT Petrokimia Gresik.Safety Communication diukur dengan 3 indikator dari Vinodkumar dan Bhasi (2010), yaitu:

a. Diskusi permasalahan keselamatan dengan atasan.

b. Pembahasan isu-isu keselamatan dalam meeting.

c. Akses informasi keselamatan.

5. Safety Rules and Procedure

Safety Rules and Procedure merupakan segala peraturan perundang-undangan yang diterapkan untuk keselamatan karyawan (Vinodkumar dan Bhasi, 2010).Dalam penelitian ini safety rules and procedure merupakan persepsi karyawan atas efektivitas peraturan perundang-undangan yang diterapkan untuk keselamatan yang diaplikasikan di PT Petrokimia Gresik.Safety Rules and Procedure diukur dengan 3 item indikator dari Vinodkumar dan Bhasi (2010), yaitu:

a. Penerapan peraturan dan prosedur keselamatan. 


\section{Jurnal Manajemen Teori dan Terapan Tahun 8. No. 3, Desember 2015}

b. Evaluasi peraturan keselamatan.

c. Penerapan sanksi pelanggaran peraturan keselamatan.

6. Safety Reward

Safety Reward merupakansuatu program insentif keselamatan yang dapat memotivasi karyawan untuk memprioritaskan keselamatan(Vredenburgh, 2002).Dalam penelitian ini Safety Reward merupakan persepsi karyawan terhadap program insentif keselamatan yang memotivasinya untuk memprioritaskan keselamatan saat bekerja yang diaplikasikan di PT Petrokimia Gresik.Safety Reward diukur dengan 1 item indikator, yaitu:

a. Adanya program insentif keselamatan

\section{Safety Knowledge}

Safety Knowledge merupakan pengetahuan karyawan terhadap praktek dan prosedur keselamatan (Vinodkumar dan Bhasi, 2010).Dalam penelitian ini safety knowledge merupakan pengetahuan karyawan terhadap praktek dan prosedur keselamatan yang diaplikasikan di PT Petrokimia Gresik.Safety Knowledge diukur dengan 3 indikator dari Vinodkumar dan Bhasi (2010), yaitu:

a. Pengetahuan menggunakan peralatan keselamatan.

b. Pengetahuan terhadap jenis-jenis bahaya kerja.

c. Pengetahuan penanggulangan situasi darurat.

\section{Safety Motivation}

Safety Motivation merupakan dorongan dalam diri karyawan untuk melakukan tindakan keselamatan (Vinodkumar dan Bhasi, 2010).Dalam penelitian ini safety motivation merupakan dorongan dalam diri karyawan untuk melakukan tindakan keselamatan yang diaplikasikan di PT Petrokimia Gresik.Safety Motivation diukur dengan 3 indikator dari Vinodkumar dan Bhasi (2010), yaitu:

a. Pentingnya menjalankan peraturan dan prosedur keselamatan.

b. Pentingnya menggunakan peralatan keselamatan.

c. Pentingnya membantu rekan kerja ketika berada dalam kondisi bahaya.

\section{Safety Performance}

Safety Performance merupakan perilaku kerja yang relevan berkaitan dengan keselamatan (Griffin dan Neal, 2000).Dalam penelitian ini Safety performance merupakan perilaku kerja yang relevan berkaitan dengan keselamatan yang diaplikasikan di PT Petrokimia Gresik.Safety Performanceada 2 dimensi:

1. Safety Compliance

Safety compliance merupakan perilaku keselamatan yang dilakukan oleh individu dalam menjaga keselamatan (Griffin dan Neal, 2000).Dalam penelitian ini safety compliance merupakan perilaku kepatuhan yang dilakukan karyawan untuk menjaga keselamatan yang diaplikasikan di PT Petrokimia Gresik.Safety Compliance diukur dengan 2 indikator dari Griffin dan Neal (2000), yaitu:

a. Menggunakan peralatan keselamatan.

b. Melaksanakan peraturan dan prosedur keselamatan.

2. Safety Participation

Safety partisipation merupakan perilaku individu untuk berpartisipasi dalam aktivitas keselamatan (Griffin dan Neal, 2000).Dalam penelitian ini safety 


\section{Novi Aditya Rosalita \\ Dwi Ratmawati \\ Tri Siwi Agustina}

participation merupakan perilaku karyawan untuk berpartisipasi dalam aktivitas keselamatan yang diaplikasikan di PT Petrokimia Gresik.Safety Participation diukur dengan 3 indikator dari Griffin dan Neal (2000), yaitu:

a. Terlibat dalam program keselamatan.

b. Membatu rekan kerja ketika bekerja dalam kondisi bahaya.

c. Memberi informasi terkait permasalahan keselamatan.

\section{HASIL PENELITIAN}

Berdasarkan responden didominasi oleh pria sebesar $87 \%$.Responden paling banyak adalah responden dengan usia 20 tahun sampai dengan kurang dari 30 tahun sebesar $45 \%$. Respondem paling banyak pendidikan SLTA sebesar $77 \%$. Responden dengan paling banyak masa kerja 1 sampai dengan kurang dari 5 tahun sebesar $54 \%$.

\section{Uji Validitas dan Reliabilitas}

Seluruh indikator variabel safety management practice $(X)$, safety performance $(Y)$, safety knowledge $\left(Z_{1}\right)$ dan safety motivation $\left(Z_{2}\right)$ dinyatakan Valid, karena memilikidiscriminant validitydengan nilai loading factor lebih besar dari 0,7 dan nilai $t$ statistic yang lebih besar dari 1,96 (tingkat signifikansi 5\%).

Seluruh variabel safety management practices $(X)$, safety knowledge $\left(Z_{1}\right)$, safety motivation $\left(\mathrm{Z}_{2}\right)$, dan safety performance $(\mathrm{Y})$ menunjukkan nilai Composite Reliability dan Cronbach Alpha di atas 0,70 , sehingga memiliki reliabilitas yang baik.

\section{R-Square}

Nilai $R^{2}$ untuk safety knowledge $\left(Z_{1}\right)$ adalah sebesar 0,3512 yang masuk kategori lemah. Nilai $R^{2}$ untuk safety motivation $\left(Z_{2}\right)$ adalah sebesar 0,3434 yang masuk kategori lemah. Adapun nilai $\mathrm{R}^{2}$ untuk safety performance (Y) adalah sebesar 0,7775 yang masuk kategori substansial.

Sebagai tambahan Nilai Stone-Geisser $\left(Q^{2}\right)$ untuk safety knowledge $\left(Z_{1}\right)$ adalah sebesar 0,2218, untuk safety motivation $\left(Z_{2}\right)$ sebesar 0,2318 , dan untuk safety performance $(Y)$ adalah sebesar 0,4838. Karena ketiga nilai Stone-Geisser $\left(Q^{2}\right)$ tersebut lebih besar dari 0 (nol) maka model dapat dikatakan memiliki relevansi prediktif bagi masing-masing konstruk tersebut.

\section{Uji Hipotesis}

Hipotesis pertama diterima karena menunjukkan bahwa safety management practices $(X)$ berpengaruh signifikan positif terhadap safety performance $(\mathrm{Y})$.

Hipotesis kedua diterima karena menujukan kondisi pertama, management practices memiliki pengaruh signifikan terhadap safety performance. Kodisi kedua, mempunyai nilai VAF sebesar 0,4086. Artinya, 40,86\% pengaruh safety management practices terhadap safety performance, dijelaskan melalui pengaruh mediasi safety knowledge. Karena nilai VAF diatas $20 \%$ tapi kurang dari $80 \%$, maka hal ini menunjukkan kondisi partial mediation (Hair et al., 2014). 
Hipotesis ketiga diterima karena menjunjukan kondisi pertama, safety management practices berpengaruh signifikan positif terhadap safety motivation dan safety motivation berpengaruh signifikan positif terhadap safety performance. Selain itu safety management practices juga berpengaruh signifikan positif langsung terhadap safety performance. Kondisi kerdua, mempunyai nilai VAF sebesar 0,5612. Artinya, $56,12 \%$ pengaruh safety management practices terhadap safety performance, dijelaskan melalui pengaruh mediasi safety motivation. Karena nilai VAF diatas $20 \%$ tapi kurang dari $80 \%$, maka hal ini menunjukkan kondisi partial mediation. Hal ini dapat dilihat dari inner model pada Gambar 2, seperti berikut:

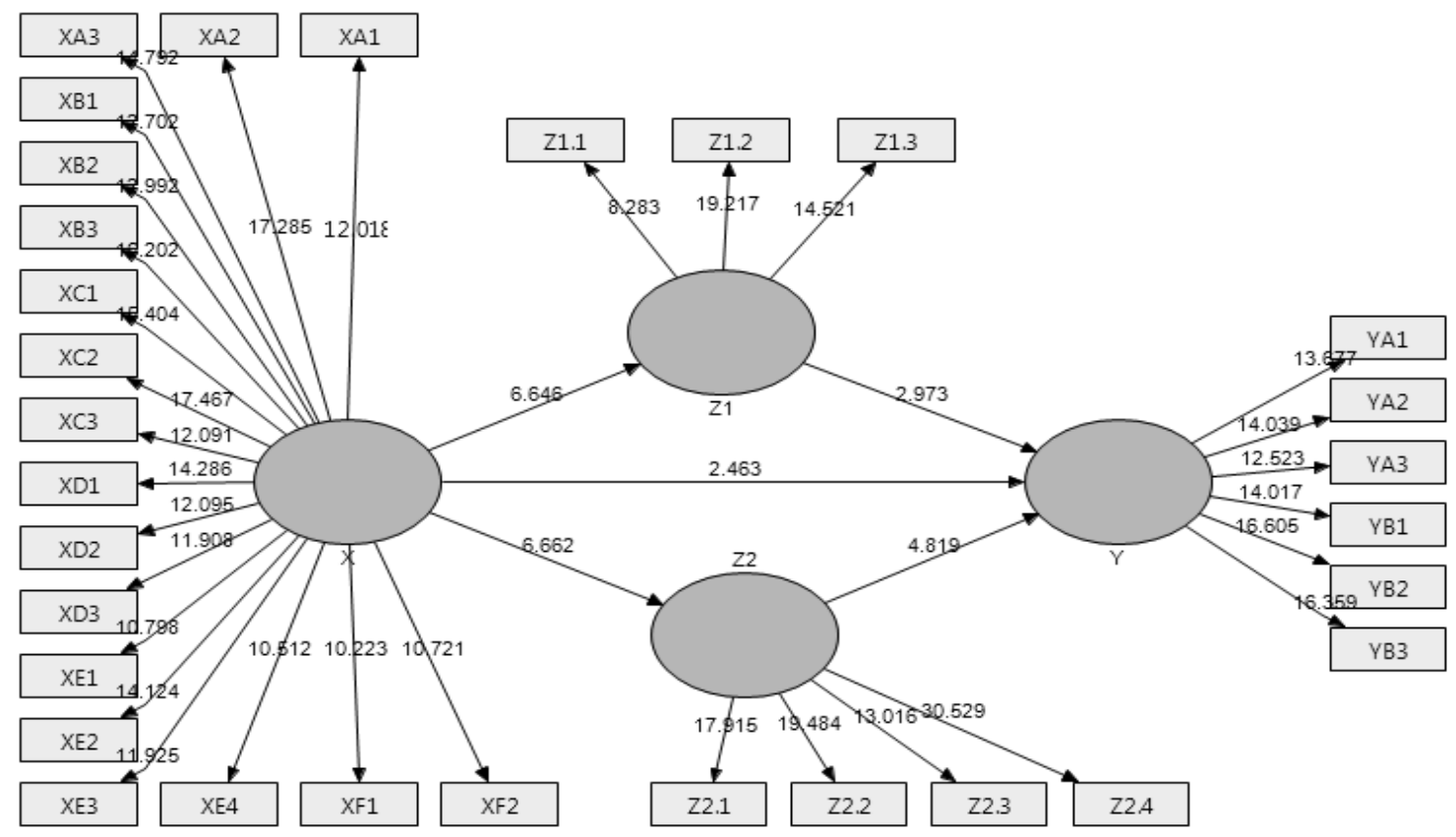

Gambar 2

Hasil Analisis Inner Model

\section{PEMBAHASAN}

Pengaruh Safety Management Practices terhadap Safety Performance

Hasil dalam penelitian menunjukan Safety Management Practices berpengaruh signifikan positif terhadap Safety Performance. Hasil penelitian ini sejalan dengan penelitian Vinodkumar dan Bhasi (2010) bahwa safety management practices berpengaruh signifikan terhadap safety performance. Signifikansi dalam penelitian ini menemukan bahwa praktek, peran, dan fungsi manajemen terkait keselamatan yang diterapkan oleh PT. Petrokimia Gresik belum cukup optimalnya (safety management practices), yang mengakibatkan belum cukup baik safety performance dari karyawan terkait perilaku keselamatan dalam menjaga keselamatan dan perilaku untuk berpartisipasi dalam aktivitas keselamatan. 


\section{Novi Aditya Rosalita \\ Dwi Ratmawati \\ Tri Siwi Agustina}

Jika dilihat berdasarkan mean variabel safety management practices masuk dalam kategori cukup, hal ini menunjukan bahwa PT. Petrokimia Gresik belum cukup optimal dalam menerapkan praktek dan fungsi manajemen untuk memperioritaskan keselamatan karyawan tentang program insentif individu sesuai dengan safety record per karyawan, akses informasi keselamatan, sanksi atas pelanggaran peraturan-peraturan keselamatan, mentor yang kompenten dibidang K3, pelibatan perwakilan karyawan (safety representative) dalam komite keselamatan, dan pengawasan pemakaian alat perlindungan diri. Hal ini yang mengakibatkan responden memiliki mean variabel safety performance yang masuk kategori cukup, sehingga karyawan cenderung berperilaku untuk mengabaikan keselamatan kerjanya seperti: karyawan cenderung belum patuh untuk menggunakan alat perlindungan diri dan belum cukup berpartisipasi dalam memberikan informasi terkait permasalahan keselamatan kepada perusahaan.

Berdasarkan karakteristik responden yang menyebabkan safety management practices dan safety performance pada PT. Petrokimia Gresik masuk dalam kategori cukup ialah sebagian besar responden pada pelaksana produksi PT. Petrokimia Gresik memiliki pendidikan terakhir SLTA sebesar 77\%, umur responden yang relatif muda dengan usia 20 tahun sampai dengan kurang dari 30 tahun sebesar $45 \%$, dengan masa kerja yang relatif pendek 1 sampai dengan kurang dari 5 tahun sebesar 54\%. Teori Tjiptoherijanto dan Nagip (2008), menyebutkan bahwa "karyawan dengan tingkat pendidikan yang tinggi akan memiliki produktivitas yang tinggi pula apalagi ditambah adanya tingkat lamanya bekerja yang dapat mempengaruhi tingkat keterampilan dan kreativitas kerjanya." Dapat dilihat bahwa responden tidak mempunyai pendidikan yang tinggi, serta masa kerja yang relatif pendek, sehingga pengetahuan, mindset, wawasan, pemahaman, pengalaman, dan kemampuan yang dimiliki responden kurang mendukung untuk penerapakan kegiatan keselamatan kerja dengan baik, sehingga responden cenderung mengabaikan kinerja keselamatannya.

\section{Pengaruh Safety Management Practices terhadap Safety Performance melalui Safety Knowledge}

Safety management practices juga terbukti berpengaruh signifikan positif terhadap safety performance melalui safety knowledge. Hasil ini konsisten dengan penelitian Vinodkumar dan Bhasi (2010) yang menyatakan bahwa safety management practices berpengaruh terhadap safety performance melalui safety knowledge.Sejalan juga dengan penelitian Griffin dan Neal (2000) yang menyebutkan bahwa safety knowledge memediasi hubungan safety climate terhadap safety performance. Signifikansi dalam penelitian ini menemukan bahwa praktek, peran, dan fungsi manajemen terkait keselamatan yang diterapkan oleh PT. Petrokimia Gresik belum cukup optimal (safety management practices), yang mengakibatkan belum cukup baik pengetahuan karyawan terhadap praktek dan prosedur keselamatan (safety knowledge), sehingga mengakibatkan belum cukup baik safety performance dari karyawan terkait perilaku dalam menjaga keselamatan dan perilaku untuk berpartisipasi dalam aktivitas keselamatan. Pengaruh safety management practices terhadap safety performance, melalui safety knowledge menunjukan kondisi partial mediation (Hair et a., 2014). Kondisi partial mediation ini mengartikan bahwa safety management practice berpengaruh 


\section{Jurnal Manajemen Teori dan Terapan Tahun 8. No. 3, Desember 2015}

secara langsung terhadap safety performance dan juga pengaruh safety management practice berpengaruh terhadap safety performance melalui safety knowledge, dengan besar pengaruh tidak langsung yang dapat dilihat dari nilai VAF sebesar $40,86 \%$.

Jika dilihat dari mean variabel safety management practices masuk dalam kategori cukup, hal ini menunjukan bahwa PT. Petrokimia Gresik belum cukup optimal dalam menerapkan praktek dan fungsi manajemen untuk memperioritaskan keselamatan karyawan tentang akses informasi keselamatan, penerapan sanksi pelanggaran peraturan-peraturan keselamatan dan mentor yang kompeten dibidang K3. Hal ini yang mengakibatkan belum cukup baik pengetahuan karyawan terhadap praktek dan prosedur keselamatan tentang pengetahuan jenis-jenis bahaya di unit kerja dan pengetahuan cara penanggulangan situasi darurat. Sehingga mengakibatkan responden memiliki mean variabel safety performance yang masuk dalam kategori cukup, sehingga karyawan cenderung berperilaku untuk mengabaikan keselamatan kerjanya seperti: karyawan cenderung belum patuh untuk menggunakan alat perlindungan diri dan belum cukup berpartisipasi dalam memberikan informasi terkait permasalahan keselamatan kepada perusahaan.

Berdasarkan karakteristik responden yang menyebabkan safety management practices, safety knowledge dan safety performance pada PT. Petrokimia Gresik masuk dalam kategori cukup ialah sebagian besar responden pada pelaksana produksi PT. Petrokimia Gresik berpendidikan SLTA sebesar 77\%, umur responden yang relatif muda dengan usia 20 tahun sampai dengan kurang dari 30 tahun sebesar 45\%, dengan masa kerja yang relatif pendek 1 sampai dengan kurang dari 5 tahun sebesar 54\%. Teori Umar (2005), menyebutkan bahwa "selain keterampilan, kapasitas kerja juga sangat bergantung pada umur tenaga kerja." dan teori Tjiptoherijanto dan Nagip (2008), "karyawan dengan tingkat pendidikan yang tinggi akan memiliki produktivitas yang tinggi pula apalagi ditambah adanya tingkat lamanya bekerja yang dapat mempengaruhi tingkat keterampilan dan kreativitas kerjanya." Umur yang relatif muda dan pendidikan rata-rata sekolah menengah atas membuat karyawan cenderung untuk mengabaikan keselamatan.Masa kerja yang relatif pendek membuat pengetahuan karyawan tidak cukup banyak, karena pelatihan keselamatan yang diikuti tidak terlalu sering, dan kurang berpengalaman untuk mengatasi kecelakaan kerja serta permasalahan keselamatan lainnya.Hal ini yang membuat safety performance dari karyawan cenderung belum cukup baik.

\section{Pengaruh Safety Management Practices terhadap Safety Performance melalui Safety Motivation}

Safety management practices juga terbukti berpengaruh signifikan positif terhadap safety performance melalui safety motivation. Hal ini sejalan dengan penelitian Vinodkumar dan Bhasi (2010) bahwa safety management practices berpengaruh terhadap safety performance melalui safety motivation. Dan sejalan dengan penelitian Grifin dan Neal (2000) bahwa safety motivation memediasi hubungan antara safety climate terhadap safety compliance dan safety participation yang merupakan dimensi dari variabel safety performance. Signifikansi dalam penelitian ini menemukan bahwa praktek, peran, dan fungsi manajemen terkait keselamatan 


\section{Novi Aditya Rosalita \\ Dwi Ratmawati \\ Tri Siwi Agustina}

yang diterapkan oleh PT. Petrokimia Gresik belum cukup optimal (safety management practices), yang mengakibatkan belum cukup baik dorongan dalam diri karyawan untuk melakukan tindakan keselamatan (safety motivation), sehingga mengakibatkan belum cukup baik safety performance dari karyawan terkait perilaku dalam menjaga keselamatan dan perilaku untuk berpartisipasi dalam aktivitas keselamatan. Pengaruh safety management practices terhadap safety performance, melalui safety motivation menunjukan kondisi partial mediation (Hair et a., 2014). Kondisi partial mediation ini mengartikan bahwa safety management practice berpengaruh secara langsung terhadap safety performance dan juga pengaruh safety management practice berpengaruh terhadap safety performance melalui safety motivatiom, dengan besar pengaruh tidak langsung yang dapat dilihat dari nilai VAF sebesar $56,12 \%$.

Jika dilihat dari meanvariabel safety management practices masuk dalam kategori cukup, hal ini menunjukan bahwa PT. Petrokimia Gresik belum cukup optimal dalam menerapkan praktek dan fungsi manajemen untuk memperioritaskan keselamatan karyawannya tentang program insentif individu sesuai dengan safety record per karyawan, akses informasi keselamatan, dan pelibatan perwakilan karyawan (safety representative) dalam komite keselamatan. Hal ini yang mengakibatkan belum cukup baik dorongan dalam diri karyawan untuk melakukan tindakan keselamatan (safety motivation) terkait pentingnya untuk melaksanakan peraturan disiplin K3 dan pentingnya untuk konsisten menggunakan alat perlindungan diri. Sehingga mengakibatkan responden memiliki mean variabel safety performance yang masuk dalam kategori cukup, sehingga karyawan cenderung berperilaku untuk mengabaikan keselamatan kerjanya seperti: karyawan cenderung belum patuh untuk menggunakan alat perlindungan diri dan belum cukup berpartisipasi dalam memberikan informasi terkait permasalahan keselamatan kepada perusahaan.

Berdasarkan karakteristik responden yang menyebabkan safety management practices, safety knowledge dan safety performance pada PT. Petrokimia Gresik masuk dalam kategori cukup ialah sebagian besar responden pada pelaksana produksi PT. Petrokimia Gresik memiliki umur yang relatif muda dengan usia 20 tahun sampai dengan kurang dari 30 tahun sebesar $45 \%$, dan masa kerja yang relatif pendek 1 sampai dengan kurang dari 5 tahun sebesar 54\%. Nampak bahwa responden yaitu karyawan pelaksana produksi pabrik III PT. Petrokimia Gresik sebagian besar memiliki umur yang relatif muda, umur yang muda ini memiliki kecenderungan tidak mempunyai keterikatan kuat terhadap perusahaan, akibatnya responden cenderung mengabaikan praktek majamen keselamatan dari perusahaan, yang disebabkan oleh belum cukup termotivasinya karyawan untuk menjaga keselamatan saat bekerja. Hal ini didukung oleh penelitian yang menyebutkan bahwa karyawan yang berusia lebih tua cenderung lebih mempunyai rasa keterikatan pada organisasi dibandingkan dengan yang berusia muda 


\section{Jurnal Manajemen Teori dan Terapan Tahun 8. No. 3, Desember 2015}

sehingga meningkatkan loyalitas mereka pada organisasi (Dyne dan Graham, 2005).Selanjutnya teori Kreitner dan Kinicki (2004) menyebutkan bahwa "masa kerja juga cenderung membuat seorang karyawan lebih merasa betah dalam suatu perusahaan, hal ini disebabkan karena telah beradaptasi dengan lingkungan yang cukup lama sehingga seorang pegawai akan merasa nyaman dengan pekerjaannya".Nampak bahwa responden memiliki masa kerja yang relatif pendek, sehingga responden tidak mudah beradaptasi dengan permasalahanpermasalahan keselamatan kerja, dan kurang berpengalaman untuk mengatasi permasalahan keselamatan kerja.Hal ini yang menyebabkan responden belum cukup termotivasi untuk selalu menjaga keselamatannya. Dapat disimpulkan bahwa seiring dengan kematangan umur dan panjangnya masa kerja akan memberikan pengalaman kepada karyawan pelaksana produksi pabrik III PT. Petrokimia Gresik dibidang keselamatan, sehingga dapat memotivasi karyawan untuk selalu menjaga keselamatan dalam bekerja, hal ini akan meningkatkan kinerja keselamatan.

Hasil analisis pada penelitian ini juga menemukan bahwa safety motivation lebih kuat dalam menjembatani pengaruh safety management practices terhadap safety performance, daripada safety knowledge. Dapat dilihat dari nilai VAF variabel safety motivation sebesar $56,12 \%$, yang lebih besar dari nilai VAF variabel safety knowledge sebesar 40,86\%. Kondisi ini menunjukkan bahwa safety motivation lebih berperan penting dalam menjembatani pengaruh safety management practices terhadap safety performance.Safety motivationakan lebih menggerakkan kepatuhan dan keaktifan karyawan dalam berpatisipasi dalam kegiatan keselamatan daripada safety knowledge. Hal ini mempunyai arti bahwa praktek manajemen keselamatan yang diterapkan oleh PT. Petrokimia Gresik tidak berarti apa-apa apabila tidak ada dorongan dari dalam diri karyawan untuk memprioritaskan keselamatan (safety motivation).Safety motivationakan lebih meningkatkan kinerja keselamatan karyawan daripada safety knowledge. Hanya mempunyai pengetahuan keselamatan saja tanpa adanya dorongan dari dalam diri untuk melakukan tindakan keselamatan (safety motivation), dapat berakibat buruk terhadap kinerja keselamatan. Oleh karena itu PT. Petrokimia Gresik harus terus memotivasi karyawan untuk meningkatkan keselamatan (safety motivation) terutama untuk mendorong karyawan untuk melaksanakan peraturan displin K3, dan mendorong karyawan untuk konsisten menggunakan alat perlindungan diri. Hal ini dapat dicapai oleh perusahaan dengan cara memupuk keterlibatan emosional karyawan, agar karyawan bersedian terlibat dalam kegiatan-kegiatan keselamatan yang diadakan oleh perusahaan. Sistem keterlibatan karyawan ini dapat menjadi ujung tombak utama dalam safety management practices, karena tujuan akhirnya juga terkait dengan peningkatan safety performance masing-masing karyawan. 


\section{Novi Aditya Rosalita \\ Dwi Ratmawati \\ Tri Siwi Agustina}

\section{KESIMPULAN}

Dapat disimpulkan bahwa (1) Safety management practices berpengaruh signifikan positif terhadap safety performance (2) Safety management practices berpengaruh terhadap safety performance melalui safety knowledge, (3) Safety management practices berpengaruh terhadap safety performance melalui safety motivation.

\section{SARAN}

Berdasarkan hasil penelitian disarankan untuk perusahaan sebagai berikut:

1. Level safety management practices pada pelaksana produksi pabrik III PT. Petrokimia Gresik masuk dalam kategori cukup terutama terkait dengan dimensi safety reward, perusahaan perlu meninjau ulang meninjau ulang program insentif individu yang disesuaikan dengan safety record per karyawan dengan cara menciptakan transparasi safety record antara perusahaan dan karyawan. Selanjutnya perusahaan juga perlu untuk meninjau ulang akses informasi keselamatan dengan memberikan kemudahan kepada karyawan seperti: mengkampanyekan informasi keselamatan yang lebih intens baik formal maupun informal melalui supervisor dan memasang poster peringatan $\mathrm{K} 3$ yang mudah dilihat atau dibaca pada tempat kerja berpotensi bahaya. Serta meninjau ulang penerapan sanksi terhadap pelanggaran peraturan-peraturan keselamatan dengan cara memberikan teguran keras, denda dan surat peringatan bagi pelanggar peraturan keselamatan. Dan didukung pula memberikan mentor yang kompenten yang teruji skill dan kompetensinya dibidang K3. Praktek-praktek manajemen tersebut jika dioptimalkan dengan baik maka dapat berkontribusi juga untuk meningkatkan level dari safety performance yang tergolong cukup, karena dapat merubah perilaku karyawan untuk lebih memprioritaskan keselamatan dalam bekerja.

2. Level safety knowledge juga masuk dalam kategori cukup, sehingga perusahaan perlu meningkatkan pengetahuan keselamatan dari karyawan terutama mengenai pengetahuan karyawan terhadap jenis-jenis bahaya di unit kerja dan pengetahuan karyawan terhadap cara penanggulangan situasi darurat. Pengetahuan keselamatan dapat diberikan kepada karyawan dengan baik apabila perusahaan memberikan mentor yang kompenten yang teruji skill dan kompetensinya dibidang K3 dalam safety training. Mentor berfungsi sebagai agen perubahan untuk mentransfer pengetahuan terkait bahaya kerja dan bagaimana cara atau metode-metode untuk mengatasi segala kendalakendala keselamatan, termasuk mempelajari cara untuk menangani situasi darurat apabila terjadi kecelakaan kerja. Mentor juga harus memberikan edukasi dan pelatihan ulang yang kontinyu dalam isu-isu keselamatan dan kesehatan kerja, karena kondisi yang selalu berubah setiap saat.

3. Level safety motivation masuk dalam kategori cukup, maka dari itu perusahaan perlu memberikan dorongan kepada karyawan untuk melaksanakan peraturan disiplin K3 dengan benar dan memberikan dorongan kepada karyawan untuk konsisten menggunakan alat perlindungan diri. Sehingga perusahaan perlu meninjau ulang meninjau ulang program insentif individu yang disesuaikan dengan safety record per karyawan dengan cara menciptakan transparasi safety record antara perusahaan dan karyawan. Serta didukung untuk meninjau ulang akses informasi keselamatan dengan mudah kepada karyawan seperti: mengkampanyekan informasi keselamatan yang lebih intens baik formal 


\section{Jurnal Manajemen Teori dan Terapan Tahun 8. No. 3, Desember 2015}

maupun informal melalui supervisor dan memasang poster peringatan K3 yang mudah dilihat atau dibaca pada tempat kerja berpotensi bahaya. Dan meninjau ulang untuk lebih melibatkan perwakilan karyawan (safety representative) dalam komite keselamatan, yang berfungsi sebagai perwakilan yang menyuarakan aspirasi karyawan terlebih untuk menjembatani permasalahan-permasalahan keselamatan antara karyawan dan perusahaan. Praktek manajemen keselamatan tersebut dapat mendorong karyawan untuk selalu mekukan tindakan yang mengedepankan keselamatan dalam bekerja.

\section{DAFTAR PUSTAKA}

Dyne, V. L, and Graham, J. W. 2005.Organizational Citizenship Behavior; Construct Redefinition Measurement and Validation.Academy Management Journal. No: 37: 765-802

Griffin, M.A., Neal, A. 2000. Perceptions of safety at work: a framework for linking safety climate to safety performance, knowledge, and motivation. Journal of Occupational Health and Psychology. No. 5: 347-358

Hair, J.F., Hult, G.T.M., Ringle, C.M., and Sarstedt, M. 2014.A Primer on Partial Least Squares Structural Equation Modeling (PLS SEM). California: SAGE Publications, Inc.

Kreitner, R. and Kinicki, A. 2004.Organizational Behavior.Fifth Edition. New York: McGraw Hill

Umar, Husein. 2005. Riset Sumber Daya Manusia. Jakarta: Penerbit PT Gramedia Pustaka Utama.

Purnamasari Wulan. 2013. Pengaruh Safty Cimate terhadap Safety Performancedengan Safety Knowledge dan Safety Motivation sebagai Variabel Intervening Studi pada Karyawan Operasional Departemen Produksi PT. Dok dan Perkapalan Surabaya (Persero)". Thesis Magister Sains Management: Universitas Airlangga

Tjiptoherijanto, P dan Nagip, L. 2008.Pengembangan Sumber Daya Manusia di Antara Peluang \& Tantangan. Jakarta: LIPI Press.

Vinodkumar, M.N and Bhasi, M. 2010. Safety Management Practices and Safety Behaviour: Assessing the Mediating Role of Safety Knowledge and Motivation. Accident Analysis and Prevention 42 (2010) 2082-2093

Vredenburgh, A.G. 2002. Organizational Safety-Which Management Practices are Most Effective in Reducing Employee Injury Rates? Journal of Safety Research. No 33: 259-276. 